\title{
15 Temmuz Darbe Girişimi Sonrasında Demokratik Bilincin Kutsal Bileşenleri
}

\author{
Doç. Dr. Yılmaz Demirhan \\ Dicle Üniversitesi, İktisadi ve İdari Bilimler Fakültesi \\ Siyaset Bilimi ve Kamu Yönetimi Bölümü \\ yilmaz.demirhan@dicle.edu.tr
}

\author{
Doç. Dr. Musa Öztürk \\ Ankara Yıldırım Beyazıt Üniversitesi, Insan ve \\ Toplum Bilimleri Fakültesi \\ Sosyoloji Bölümü \\ mozturk@ybu.edu.tr
}

Öz

Bu çalışma, 15 Temmuz 2016 tarihinde ordu içerisindeki FETÖ mensuplarınca gerçekleştirilen darbe kalkışmasının bastırılmasından sonra kamu düzeninin yeniden tesisi ve demokratik düzenin tahkimi amacıyla devletin bazı araçlardan nasıl yararlandığını açıklamayı amaçlamaktadır. Bu çerçevede önce Türkiye'de demokratikleşme süreci ve bu süreci kesintiye uğratan darbe ve darbe girişimleri hakkında bilgi verilmiştir. Daha sonra 15 Temmuz kalkışması ardından hükümetin dinî, askerî ve toplumsal alandan özenle seçtiği bazı sembol, simge, ritüeller etrafında yeni bir kolektif bilinç inşa edilme çabasına dikkat çekilmektedir. Çalışmada, sosyolojik araştırmalarda yaygın olarak kullanılan kuramsal yaklaşımlardan biri olan sembolik etkileşimci bakış açısından yararlanılmıştır.

Anahtar Kelimeler: FETÖ, 15 Temmuz, semboller, ritüeller, demokrasi.

\section{The Sacred Components of Democratic Consciousness After July 15 Coup Attempt}

\section{Abstract}

This study aims to explain how the state benefited from some tools to reorganize public order and consolidate the democratic order after the suppression of the coup attempt by the members of FETO (Fethullahist Terror Organization) in the army on 15 July 2016. In this context, firstly, brief information is given about Turkey's democratization process and coups and coup attempts that interrupted this process. Then, after July 15 coup attempt, attention is drawn to the effort of the government to build a new collective consciousness around some symbols, icons and rituals which were selected by it from religious, military and social spheres. This study includes the symbolic interactionist perspective which is one of the theoretical approaches widely used in sociological researches.

Keywords: FETO, July 15, symbols, rituals, democracy. 


\section{GíRIŞ}

Ulusçuluk hareketlerinden en çok imparatorluklar etkilenmiştir. Bunların başında Osmanlı Devleti ve Avusturya-Macaristan imparatorluğu gelmektedir. Balkan Savaşları (1912-1913) ve akabinde cereyan eden I. Dünya Savaşı (1914-1918) sonrasında pek çok etnik unsur Osmanlı Devletinden ayrılarak ulusal bağımsızlığına kavuşmuştur. I. Dünya Savaşı sonrasında işgale uğrayan Osmanlı toprakları üzerinde Kurtuluş Savaşı (1919-1922) sürecinde verilen uzun, zorlu ve çetin bir mücadele sonucunda Türkiye Cumhuriyeti (1923) kurulmuştur.

Cumhuriyetin ilk döneminde gerçekleştirilen reformlar büyük ölçüde Osmanlı'nın son döneminde girişilen reformların bir devamı niteliğindedir. Bu anlamda Cumhuriyet' $\mathrm{i}$ kuran kadronun topluma bakış açısı ile Osmanlının son dönemindeki yönetici sınıfın topluma bakışı büyük ölçüde birbirine benzemektedir. Öyle ki yeni Türkiye Cumhuriyeti'nde devletin idare şekli Cumhuriyet olmasına ve bu durum anayasada Halkçılık başlığı altında ifade edilmesine rağmen, dönemin yöneticileri reformları gerçekleştirirken halkı yönetime ve karar alma süreçlerine dahil etmemişlerdir. Ne askerler II. Abdülhamit'i tahttan indirirlerken ne de Cumhuriyetin kurucu kadrosu Saltanatı ve Halifeliği kaldırıp iktidar ve bağlı müesseselerin yetkilerini millet iradesinin yeni temsilcisi olarak kabul edilen Türkiye Büyük Millet Meclisi (TBMM)'ne aktarırken ciddi bir halk direnişiyle karşılaşmamışlardır.

Halk arasında Orduya karşı çıkmama, askerlere karşı direnmeme anlayışının sonraki dönemlerde de devam ettiği görülmektedir. Mesela; 27 Mayıs 1960'ta, 12 Mart 1971'de, 12 Eylül $1980^{\prime}$ de askerler siyasete doğrudan ve 28 Şubat $1997^{\prime} \mathrm{de}^{1}$ de dolaylı olarak müdahale ettiklerinde toplumdan ciddi bir tepkiyle karşılaşmamışlardır. Hatta 27 Nisan 2007 gecesi Genel Kurmay Başkanlığı'nın internet sitesine konulan ve uzun bir süre de sitede yayında kalan Elektronik Muhtıra'ya (E-Muhtıra) hükümet dışındaki/haricindeki siyasi çevrelerden ve halktan güçlü bir sivil tepki ortaya konulamamıştır. Toplumun ve siyaset kurumunun bu tepkisizliği yaklaşık olarak her on yılda bir tekrarlanan darbe veya darbe girişiminde bulunan gruplara dolaylı olarak cesaret vermiştir denilebilir.

Türk halkının geleneksel olarak askere karşı çıkmaması ordu içerisinde darbe yanlısı fikirlerin zemin bulmasını kolaylaştırıcı bir işlev görmüştür. Halkın demokrasiye sahip çıarak darbecilere veya darbeye teşebbüs edenlere direnç göstermemesi pek çok kez askerleri siyasal iktidarlara karşı darbe planlarken cesaretlendirmiştir. Küçük bir kesim dışında halkın kahir ekseriyeti darbeleri meşru görmese de halk; darbecilere olan tepkisini sokaklara inerek, meydanlarda toplanarak değil de sandıkta dile getirmeyi tercih etmiştir. Bununla birlikte darbeye maruz kalan siyasal iktidarlar ve siyasal parti temsilcileri de darbecilerin eylemlerini genellikle sessiz sakin biçimde kabul etmiş ve adeta her seferinde kaderlerine razı olmuşlardır. Bunda elbette 1960 darbesi neticesinde başbakan Adnan Menderes ve iki bakanının (Fatih Rüştü Zorlu ve Hasan Polatkan) idam edilmelerinin büyük etkisi olmuştur. Darbeye direnme ihtimalini düşünen her siyasetçinin zihnine bu büyük acının resmi kazındığından direnme düşünceden pratiğe geçememiştir. Buna rağmen her darbe girişimi sonrasında siyaset kurumu büyük yaralar almıştır. Siyasiler ve siyasi partiler darbeye diren(e)memiş olsalar da çeşitli şekillerde cezalandırılmaktan kurtulamamışlardır.

\footnotetext{
${ }^{1}$ Türkiye' deki askeri darbe ve darbe teşebbüsleri hakkında ayrıntılı bilgi için bkz.

Mehmet Barlas (2000), Türkiye' de Darbeler ve Kavgalar Dönemi, Birey Yayınları; Ali Bayramoğlu (2018), 28 Şubat Bir Müdahalenin Güncesi, İletişim Yayınları; Çetin Yetkin (2011), Türkiye'de Askeri Darbeler ve Amerika, Kilit Yayınları; Cemil Koçak (2017), Darbeler Tarihi, Timaş Yayınları.
} 
Siyasi partilerin kapatılması, parti liderleri ve bazı parti üyelerinin belirli bir süre siyasetten men edilmeleri ve bazılarının hapis cezasına çarptırılmaları bunlar arasında sayılabilir.

Osmanlı döneminden beri devam eden bu gelenek 15 Temmuz 2016 ile değişmiş, o gece adeta Türkiye'de yeni bir dönemin başlangıcı olmuştur. Darbe girişimi esnasında Cumhurbaşkanı Recep Tayyip Erdoğan'ın gece 00:22'de CNN Türk'ten Hande Frrat'ın programına bağlanıp vatandaşları direnmeye davet etmeden önce halkın bir kısmı inisiyatif alarak sokağa inmiştir. ${ }^{2}$ Cumhurbaşkanının çağrısı ile artan sivil kitle darbeci askerlere karşı direnerek (silaha ve şiddete başvurmadan) darbenin püskürtülmesinde tarihi bir rol oynamıştır. Halkın inisiyatif alarak darbecilere karşı direnmesi ezberleri bozmuş, darbecileri hayal kırıklığına uğratmıştır. Bu durum Türkiye'de geç de olsa demokrasi kültürünün kök salmaya başladığının, demokratik kazanımların halk tarafından içselleştirildiğinin bir göstergesi olarak yorumlanabilir.

Halk, 15 Temmuz gecesi daha önce yapılmamış olanı yaparak darbe girişiminin önlenmesinde büyük pay sahibi olurken, siyasal iktidar da 15 Temmuz'u takip eden günlerde bu direniş ruhunu diri tutmak için yeni bazı adımlar atmıştır. Bu kapsamda hükümet, Türk demokrasi tarihi açısından yeni bir milad oluşturma adına bazı simge, sembol ve ritüeller üzerinden demokratik ruhu canlı tutarak bu sürecin toplum tarafından sahiplenilmesini öncelemiştir. Dinî, askerî ve toplumsal/kamusal alanlardan seçilen bazı simge, sembol ve ritüeller etrafında yeni bir birliktelik ruhunun oluşturulmaya çalışıldığı dikkati çekmektedir. Diğer bir ifadeyle demokrasi, milliyetçilik ve beka kaygısı etrafında kümelenen kolektif enerji, ritüeller vasıtasıyla belirli kalıplara dökülerek demokrasinin tahkimine tevlit edilmiştir. Demokratik bilinç kutsal bileşenler etrafında yeniden yoğurulmaya başlanmıştır. Bu anlamda 15 Temmuz sonrasında belirli simgeler üzerinden toplumu demokrasi etrafında bütünleştirecek yeni bir "birlik" literatürünün çok hızlı bir şekilde hayatımıza girmeye başladığı görülmektedir.

Çalışmada ilk olarak Türkiye'de askeri müdahaleler hakkında bilgi verilecek; ardından 15 Temmuz sonrasında siyasal iktidar tarafından belli alanlardan (dinî, siyasî, askerî) seçilen bazı özel söylem, simge ve sembollerin topluluk ve kültür oluşturucu etkileri üzerinde durulacaktır. Bunların siyaset sosyolojisi açısından demokratik bilincin/demokrasi bilincinin ve demokrasi kültürünün derinleşmesine ne düzeyde katkı sağlayabileceği tartışlacaktır. Çalışmada sosyolojik araştırmalarda yaygın olarak kullanılan kuramsal yaklaşımlardan biri olan "sembolik etkileşimci bakış açısı"ndan yararlanılmıştır.

\section{Türkiye'de Demokrasi ve Askeri Darbeler}

Türkiye Cumhuriyeti Osmanlı mirası üzerine kurulmuştur. Bu yüzden Osmanlı geçmişi dikkate alınmadan modern Türkiye tarihi tam olarak anlaşılamaz. Türkiye Cumhuriyeti Osmanlı'nın tek mirasçısı olmasa da Osmanlı temelleri üzerinde en dolaysız şekilde kurulmuştur. Osmanlı' dan Cumhuriyet'e intikal eden coğrafya tasavvuru, 1918'den sonra aniden gerçekleşmemiştir. 19. Yüzyılın son çeyreğinden itibaren toprak kayıplarının hızla artması (ayrılanların kendi ulus-devletlerini kurmaları) son dönem Osmanlı yöneticilerinin zihnindeki devlet tasavvurunun imparatorluk sonrasına intikal etmesini kolaylaştırmıştır. Sınırların ve halkların tanımı günden güne değişip daha çok tartışmaya

2Andy-Ar'ın 19 Temmuz'da 1.496 kişiyle telefondan/telefonla yapmış olduğu ankete göre halkın \%65,7'si
Cumhurbaşkanı Recep Tayyib Erdoğan'ın davetiyle sokağa ç1kmıştır. Aynı arştırmaya göre halkın \%72,6's1 rütbeli
askerlerin arkasında başka devletlerin olduğunu düşünmektedir. https://onedio.com/haber/15-temmuz-sonrasi-ilk-
anket-sokaga-kimler-cikti-tehlike-gecti-mi--724413, (28 Ocak 2019). SEFAD, 2020; (43): 405-420 
açık hale geldikçe, devlet ideali Osmanlı reformcularının zihinlerindeki açıklık ve saflığını korumaya devam etmiştir. Bu kadrolar Türkiye Cumhuriyeti'nin idarecileri haline gelince, kendi hayallerinde kurdukları devlet idealine duydukları sadakati Cumhuriyet'e yöneltmişlerdir. Osmanlı İmparatorluğu'nun ardından gelen diğer devletler ondan miras olarak çok şey almışlarsa da aralarında bu türden bir süreklilik söz konusu olmamıştır (Findley, 2011, s. 5-6).

Findley'in de belirttiği gibi (yaygin bir biçimde akademik dünyada da kabul gören bu görüşe göre) Türkiye Cumhuriyeti bir bakıma Osmanlı'nın son iki yüzyılında başlayan modernleşme ve demokratikleşme arayışlarının zorunlu olarak başka bir form içinde ortaya çıkmış bir sonucudur. Bu nedenle eğer Türkiye'de demokrasinin kurumsallaşmasından ve bu kurumsallaşmayı zaman zaman kesintiye uğratan askeri darbelerden bahsedilecekse mutlaka Osmanlı dönemindeki öncüllerine ve kurucu unsurlarına, bu dönemde yenilikçi kesim ve gelenekçiler arasında yaşanan siyasi gerilimlere ve buna bağlı olarak ortaya çıkan siyasi, hukuki, dini, idari değişmeler ile yasal kurumsal oluşumlara bakmak gerekmektedir.

Türkiye'de demokrasi deneyiminin ilk adımı Sened-i İttifak'a (1808) kadar geri götürülebilse de esas anlamda bu deneyim Tanzimat Fermanı (1839) ile başlamıştır. Tanzimat Fermanı'nın temel özelliği Osmanlı Devleti'nde tebaadan vatandaşlığa geçişin başlangıç noktasını teşkil etmesidir. Demokrasi deneyiminin ikinci adımını ise Islahat Fermanı (1856) oluşturmaktadır. Islahat Fermanı'nın temel özelliği ise Osmanlı tebaasının her alanda eşitliğini sağlamasıdır. Demokrasi deneyiminin üçüncü adımını ise Kanun-ı Esasi (I. Meşrutiyet 1876) teşkil etmektedir.

Tanzimat ve Islahat fermanlarıyla karşılaştırıldığında Kanun-u Esasi daha üst, çatı bir hukuki düzenlemeyi içermektedir. Kanun-u Esasiyle birlikte padişah ilk defa egemenlik haklarından bazılarını meclisle paylaşmıştır. Sultan II. Abdülhamit iktidara geldikten kısa bir süre sonra patlak veren Osmanlı Rus Savaşı (1877-1878) gerekçesiyle meclisi feshederek Anayasa'yı (Kanuni Esasi'yi) askıya almıştır. Uzun yıllar kapalı kalan meclis ancak II. Meşrutiyet döneminde açılmıştır. 1908 yılında ilan edilen II. Meşrutiyet, 1918 yılına kadar sürmüştür. 1908-1918 arası demokrasi açısından tami bir laboratuvar özelliği taşımaktadır (Çaha, 2011, s. 223). İlber Ortaylı II. Meşrutiyetin ilanını modern Türkiye tarihi açısından şöyle değerlendirmektedir:

\begin{abstract}
"1908 devrimi anayasal sistemde önemli yeni kurumlar yaratmıştır. Bunların basında toplumsal hayatımızda siyasal partilerin vazgeçilmez öğeler olarak doğusu, derneklerin faaliyeti, toplantı, gösteri ve grev hakları, basın özgürlüğ̈̈ yer alır. 1908'den sonra İstanbul'da ve diğer vilayetlerde yapılan iki dereceli seçimlerle Meclis-i Mebusan yeniden toplanmıştı. II. Mesrutiyet döneminin ilk yılları siyasal hürriyetlerin kullanılışı, çeşitli düşünce akımlarının ortaya çıkıp örgütlenmesi yönünden Türkiye tarihinin altın sayfalarından biri sayılmalıdır. II. Mesrutiyet'te toplum ve devlet hayatımızda laik bir sisteme geçiş de başlamıştır. Gene eğitim kurumlarının da ilköğretim düzeyinden ele alınıp laik bir yaklaşımla yeniden düzenlenmesine girişildiği görülmekteydi. Darülfünun'un, yani üniversitemizin özerkliği de bu dönemde gündeme gelen ve kısmen gerçekleştirilebilen, Türk eğitim tarihinin onurlu bir olayıdır (Ortaylı, 2001: 64)."
\end{abstract}

İttihat ve Terakki yönetimde iken başlayan I. Dünya Savaşı'na Osmanlı Devleti, Almanya'nın yanında girmiştir. İtilaf devletlerinin savaşı kazanmasının Osmanlı Devleti üzerindeki en önemli etkisi Osmanlının parçalanması olmuştur. I. Dünya Savaşı'nı takip eden yıllarda cereyan eden Kurtuluş Savaşı sonunda Cumhuriyet'e geçilmiştir. 
İmparatorluktan ulus-devlete geçiş Cumhuriyetin ilanı ile gerçekleşmiştir. Gerçekleştirilen seçimlerde o günkü mecliste yer alan Birinci ve İkinci Grup yarışmış ve seçim Birinci Grubun zaferiyle sonuçlanmıştır. Daha sonra Birinci Grup, Cumhuriyet Halk Partisi'ne dönüşmüştür. İkinci Grup ise 1924'te Terakkiperver Cumhuriyet Fırkası'nı kurmuş, fakat daha sonra Fırka, Şeyh Sait İsyanı (1925) ile ilişkilendirilerek kapatılmıştır. Cumhuriyet Halk Partisi'nin güdümünde oluşturulan Serbest Cumhuriyet Fırkası (1931) deneyimi de kısa sürmüş, fırka kurulduktan kısa bir süre sonra kendisini feshetmek zorunda kalmıştır. Haliyle CHP, ülkeyi 1950 yılına kadar fiili olarak tek parti sistemi ile yönetmiştir (Tunçay, 2015, s. 140, 234).

II. Dünya Savaşı'nda (1939-1945) tek-parti yönetimindeki Nazi ve Faşist rejimleri (Almanya, İtalya vb.) yenilip, savaşı demokrasi cephesi kazanınca; dünyada demokratikleşmeye doğru bir eğilim yaşanmıştır. Türkiye savaş boyunca denge politikası izlemiştir. Fakat savaş sonrasında tek-parti diktatörlüğündeki SSCB'nin de kazananlar safında yer alması Türkiye'yi bir tercihte bulunmaya zorlamıştır. Türkiye, tercihini demokrasi cephesinden yana kullanarak 1946 yllında çok partili hayata geçmiştir. Savaştan sonra CHP'den Dörtlü Takrir krizi ile ayrılanlar 1946 yılında Demokrat Partiyi (DP) kurmuştur. 1946 seçimlerinde açık oy gizli sayım yönteminin uygulanması seçimleri şaibeli hale getirmiştir. Sayım sonrasında seçimden CHP, birinci parti olarak çıkmış ve 4 yıl daha tek başına iktidarda kalmıştır. Gizli oy açık sayım ve sandıkta hâkim denetiminin hayata geçtiği 1950 seçimleri açk ara DP'nin zaferi ile sonuçlanmıştır. 1954 ve 1957 yıllarında yapılan seçimlerde de DP iktidarını sürdürmüştür. 27 Mayıs 1960 askeri darbesiyle (Çaha, 2011, s. 235) DP iktidarı sona ermiştir. Yassıada' da yapılan yargılama sonucunda başbakan, dışişleri ve maliye bakanları idam edilmiş, pek çok milletvekili tutuklanmış, ordu içinde ise tasfiyeye gidilmiştir. Darbenin ardından yeni bir anayasa hazırlanarak devlet yeniden yapılandırılmış ve iki meclisli bir sisteme geçilmiştir.

Darbeden sonra Türkiye'de bir normalleşme (demokratikleşme) süreci başlasa da 12 Mart 1971 Askeri Muhtırası, 12 Eylül 1980 Askeri Darbesi, 28 Şubat 1997 Postmodern Darbesi, 27 Nisan 2007 Askeri e-Muhtırası bu normalleşmeyi tersine (otoriterleşme) çevirmiştir. Askerlerin sistematik olarak her on yılda bir siyasete müdahale etmeleri onların kendilerini sivillerin çözemediği sorunları çözen, rejimin tehlikeye girmesini önleyen, devletin sahibi kadrolar/kişiler olarak görmelerine neden olan yanlış bir zihniyetin gelişmesine yol açmıştır. Bu anlayışın son halkası 15 Temmuz 2016 gecesi sivil siyasal iktidara karşı girişilen darbe teşebbüsüdür.

Özellikle askeri, sivil ve yargı bürokrasisinde İslami cemaat görünümü altında çok güçlü bir şekilde örgütlenen bir grup hükümetle çeşitli konularda ters düşmüş ve günden güne bu durum hükümetle aralarında gerilimin yükselmesine sebep olmuştur. 2012 ve 2013 yılında yargı üzerinden hükümete karşı gerçekleştirilen operasyonların ardından hükümet söz konusu yapıya karşı sert tedbirlere başvurmuştur. 26 Mayıs 2016 tarihinde yapılan MGK toplantısında devlet ilgili yapıyı Fethullahçı Terör Örgütü (FETÖ) olarak tanımlayarak terör örgütleri listesine almıştır. O tarihten itibaren devlet, FETÖ'yü devletten temizlemeye, dayandığı temelleri zayıflatmaya yönelik son derece güçlü adımlar atmıştır.

Devletten tamamen tasfiye ile yüz yüze kalan örgüt, son hamlesini 15 Temmuz 2016 gecesi gerçekleştirmiştir. Ordu içindeki güçlerini harekete geçiren örgüt; uçaklar, helikopterler, zırhlı araçlar, tanklar, ağır silahlar kullanarak hükümete karşı darbe girişiminde bulunmuştur. Cumhurbaşkanı ve başbakan halkı darbeye ve darbecilere karşı çıkmaya çağırmış, güvenlik ve yargı güçleri ile ordu içinde darbeden yana olmayan 
askerlerin mukavemeti ile darbe teşebbüssü başarısız kılınmıştır. Kalkışmanın bastırılması esnasında 248 kişi şehit olmuş, binlerce kişi ise yaralanmıştır. Türkiye, benzer durumlarla karşılaşan pek çok devletin yaptığı gibi 21 Temmuz 2016 günü Olağanüstü Hal (OHAL) ilan etmiştir.

Devletler olağanüstü hal ilan etme konusunda bağımsız yetkilere sahiptir ki bu onun varlık nedenidir aynı zamanda. Eğer bu yetki kabul edilmezse o zaman devletin varlığından bahsedilemez. Karl Schmitt acil, sıra dışı veya inzibati durumlarla ilgili alınan bazı tedbirleri veya kanuni düzenlemeleri olağanüstü hal olarak nitelendirmez. "Olağanüstü halden bahsedebilmek için prensip olarak sınırsız yetkinin söz konusu olması, yani mevcut düzenin bütünüyle askıya alınması gereklidir. Böyle bir durumda hukuk geri adım atarken devletin baki kalacağı aşikârdır. Olağanüstü hal, anarşi ve kaostan farklı bir şey olduğu için hukuk düzeni değilse de, hukuki anlamda bir düzen hala mevcuttur. Burada, devletin varlığı, hukuki normun geçerliliğ̈i karşısında tartışmasız üstünlüğünü kanıtlar. Karar, kendini tüm normatif bağlardan kurtarır ve gerçek anlamda mutlak hale gelir. Olağanüstü halde devlet; hukuku, kendini koruma hakkına dayanarak askıya alır (Schmitt, 2005, s. 19). Anayasal düzeni ortadan kaldırmaya teşebbüs eden bir askeri kalkışmanın cari hukuk yolları kullanılarak önlenmesi mümkün değildir. Çünkü kalkışma aynı zamanda onu da ortadan kaldırmayı hedeflemektedir.

Olağanüstü hal ilan edilmesini gerektiren şartlar vukuu bulduğunda cari hukuki düzenin işleyeceği zemin ortadan kalktığından hukuki sistem tıkanmaktadır. Devletler bu tür durumlar karşısında tekrar normal düzene geçebilmek için geçici bir süreliğine cari hukuku askıya almak zorunda kalmaktadırlar. "Norm, homojen bir ortama ihtiyaç duyar. Bu fiili normal durum, yalnızca hukukçunun göz ardı edebileceği 'yüzeysel bir varsayım' değildir, daha çok kendi içkin geçerliliği ile ilgilidir. Hiçbir norm yoktur ki bir kaos durumunda uygulanabilsin. Hukuki düzenin anlamlı olabilmesi için bir düzenin oluşturulmuş olması zorunludur. Normal bir durum yaratılmalıdır ve egemen, bu durumun gerçekten hüküm sürüp sürmediğine kesin bir biçimde karar verendir. Her kanun "somut olaya uygulanan kanundur" [Situationsrecht]. Egemen, durumu kendi bütünselliği içinde yaratır ve garanti altına alır. Bu son karar onun tekelindedir. Devlet egemenliğinin özü burada yatar ve hukuken zorlama veya hükmetme tekeli olarak değil, olması gerektiği gibi karar verme tekeli olarak tanımlanır" (Schmitt, 2005, s. 20). Devlet, demokratik düzenin işleyişinin önündeki ve üzerindeki engelleri ortadan kaldırarak normal hale dönmek için olağanüstü hali bir kalkan olarak kullanır.

15 Temmuz 2016 darbe girişimi sonrası OHAL sürecinde siyasal iktidar hemen gerekli yasal düzenlemeleri yapmış, hukuki cezai tedbirler almış, darbeye katılanları, darbeden yana olanları cezalandırma ve görevden uzaklaştırma yoluna gitmiştir. Aynı sürede vatandaşın darbe ve darbecilere karşı tepkisini diri tutmak, olası başka darbe girişimlerini engellemek için dini, askeri ve siyasi alanlardan seçtiği bazı sembol, simge ve ritüellerden istifade ederek halktan gelen geniş demokratik refleksi yönetmeyi/geliştirmeyi başarmıştır. Demokrasinin kutsal bileşenleri üzerinden aşağıdaki başlıkları üzerinden yeni bir kolektif bilinç oluşturulmaya çalışılmıştır.

\section{Araştırmanın Yöntem ve Metodolojisi}

İnsanın en önemli özelliklerinden birisi simge, sembol ve ritüeller üreterek bunların etrafında bir kültür oluşturabilmesidir. Bunlar kültürel yapının ve toplumsal düzenin sacayağını oluştururlar. Simge, sembol ve ritüellerin tarihsel süreç içerisinde geçirmiş 
oldukları serüvenler insan zihninin yaratıcıllğının gücünü ortaya koymaktadır. Bu icat ve inşa süreci başta din olmak üzere siyasal yapıyla da sürekli etkileşim halindedirler.

Çalışmada sosyolojik araştırmalarda yaygın olarak kullanılan "sembolik etkileşimci bakış açısı"ndan yararlanılmıştır. Sembolik etkileşimciler insanların algılarının simgeler aracıllğıyla kurdukları etkileşim sürecinde oluştuğunu ileri sürerler. Bireylerin düşünme kapasitesi toplumsal etkileşim tarafından şekillendirilmektedir. Bireyler sosyalleşme sürecinde öğrendikleri anlamlar ve semboller vasıtasıyla birbirleriyle ve toplumla etkileşimlerini sürdürmektedirler. Toplumdaki sosyal grupların, toplumla iç içe geçmiş eylem ve etkileşim kalıplarının temeli ortak anlam ve sembollere dayanmaktadır (Ritzer, 2011, s. 227).

Şerif Mardin, toplumun varlığını sürdürmesinde simge dağarcığı kavramına dikkatimizi çekmektedir. Toplum, yapısal olarak "şekli"ni topluluktaki yaşayan herkesin zihninde taşıdığı simge dağarcıklarından almaktadır. Kültür aktarımı araçları/ajanları olarak simgelerin nesilden nesile aktarılmasıyla insanlar aynı/benzer toplumsal davranışta bulunmayı öğrenmektedirler. Sosyal öğrenme süreci simgelere dayalı olarak gerçekleştiğinden simgeler üzerinden toplum içerisinde birden çok kimsenin paylaştığ anlam haritası ortaya çıkmaktadır. Sembolik etkileşimciler (G. H. Mead, E. Cassirer, J. Piaget) insanların algılarının sadece dış etkiler sonucunda değil, aksine bir 'simgeselleştirme' süreci sonucunda ortaya çıtığını iddia ederler (Mardin, 2013, s. 90-91). Hatta bu anlamda Mardin insanların dünyayı 'simge sistemi gözlügü̈yle gördüklerini belirtirken, bilginin toplum tarafından şekillendirilmesine dikkat çekmektedir. Mardin insanların bilgiyi 'tabiat'tan değil 'toplum'dan aldıklarını, toplumdan alınan bilginin ise şekillen(diril)miş bilgi olduğunu 'padişah' ve 'devlet' simgeleri üzerinden şöyle açıklar: "Geleneksel toplumda anne çocuğuna "padişah"tan bahsettiği zaman o simgeyi gereken "hürmet" ağırlığını vererek intikal ettirir. Bugün de baba "devlet"i andığı zaman aynı çağrışımın oğlunun düşüncesine geçmesine dikkat eder (Mardin, 2013, s. 91)".

Sembolik etkileşimciler simgelerin özetleyici ve soyutlayıcı özelliklerine dikkat çekerler. İnsanlar içinde yaşamış oldukları toplumun karmaşık, anlaşılması zor durumlarını simgeler dizisi sayesinde anlamlandırırlar. Simgelerin; "Dünyamızın içindeki nesneleri sınıflandırma, yaşadığımız toplulukta önemli tutulan değerlerin neler olduğunu hatırlatma ve onlara uymayı zorlama, bu değerleri içerme, bazı hislerimizi boşaltma ve açığa dökme, son olarak da bilişsel evren kurma" (Mardin, 2013, s. 96-97) gibi dört önemli fonksiyonu vardır. Kısaca ifade etmek gerekirse simgeler, toplumsal kabullerimiz ve retlerimiz etrafında oluşturduğumuz sinıflamaları özetlerler. Bu bağlamda 15 Temmuz sonrasında hayatımıza giren bazı simge, sembol ve toplumsal etkinlikler ve de bunların etrafında oluşturulmaya çalışılan ritüellerin toplumsal bütünleşmeye olan etkileri ele alınacaktır.

\section{Sosyal Düzenin Sembolik İfadeleri Olarak Ritüeller}

Toplumsal hayatta ritüellerin etkili olduğu alanların başında din gelse de ritüeller salt olarak dini alana veya dinlere hasredilemez. İlk başlarda din/teoloji tarafından kullanılan terim bugün; sosyoloji, antropoloji, psikoloji, vb. bilimler tarafından da kullanılmaktadır. Ritüelin dini alandan dindışı diğer alanlara doğru genişlemesi bazı gelenek ve seremonilerin ritüel sayılıp-sayılmayacağı yönündeki bir tartısmayı beraberinde getirse de sosyologlar seremoni ile ritüeli birbirinden ayırmaktadırlar.

Van Gennep, ritüelin toplumsal bütünleşme ve kimlik edinme sürecindeki katkısını belirtirken insanın yalnızca toplum içine doğmadığını, aynı zamanda toplumsal bir eylem 
olarak geçiş törenleri aracılığıyla yeniden yaratıldığını belirtir (Marshall, 1999, s. 624). Birey ritüeller vasıtasıyla kademeli olarak toplumun içine çekilirken bunlar etrafında oluşan anlam öbekleri tarafından çevrelenmektedir. Her birey kendi anlam dünyasını onların içinden düşünerek kurduğundan ritüellerin varlığından veya işlevinden pek şüphe etmemektedir. Normal şartlar altında onlara uygun davranarak hem kendisini toplumsal korumaya almakta hem de onları onayarak yeniden üretmektedir.

Ritüeller çoğunlukla dini karakterli olsalar da modernleşme sürecinde pek çok yeni seküler ritüelin üretildiği dikkatimizi çekmektedir. Üretilen bu ritüeller modern siyasal simgeciliğin bilmeyle, kutsallıkla ve zamanla ilişkilerini içeren genel bir varsayımı da bünyesinde taşımaktadır (Abélés, 1998, s. 150). Toplumlar, yaşamakta oldukları krizleri aşmak ya da yapısal ve kültürel dönüşümleri sistematize etmek için yeni bazı ritüeller üretirler. Ritüellerin etkileri ritüel zamanlarıyla sınırlı değildir. Ritüeller, ritüele katılanlar arasında oluşan grup bilinci ve kolektif şuur vasıtasıyla toplumsal kimliği tanımladıkları (Karaman, 2010, s. 236) gibi, aynı zamanda kimliği kuran ve koruyan bilgiyi ileterek/devrederek kültürel kimliği yeniden inşa ederler (Assmann, 2015, s. 65).

Ulus-devletlerin kuruluş sürecinde bir yandan önceki dönemlerde oluşan kimliklerden radikal kopuş yaşanırken, diğer yandan tarihsel kök oluşturulmaya çalışılarak yeni ulusal kimlikler temellendirilmeye çalışılmıştır. Türk toplumunda bu sürecin, 'Padişahım çok yaşa'dan 'Ne mutlu Türküm diyene', saltanat sisteminden Cumhuriyete, millet sisteminden millet meclisine, İslam tarihinden Türk tarihine (Tekeli, 2009, s. 54) geçiş şeklinde gerçekleştiği görülmektedir. Cumhuriyetin ilk yıllarında yeni bir ulus ve kimlik inşa etmek için saltanat ve İslam mirası bir kenara konularak yeni kimlik, İslam öncesi Türk tarihiyle temellendirilmeye çalışılmıştır.

Pierre Bourdieu $(2015,19 ; 2006$, s. 116) devletin toplumsal düzene ve toplumsal düzenin temel ilkelerine iştirak anlamında rızayı örgütlemede operasyonel bir yapıya sahip olduğunu belirtir. Devlet uygulamış olduğu baskı ve disiplin aracıllğıyla toplumsal gerçeklik, örgütsel yapı ve pratikleri ve de bedensel ve zihinsel yatkınlıkların üretim ve yeniden üretiminde başat rol oynar. Eğitim, medya ve kültür gibi aygıtları tekelinde tutarak zihni yapıları belli değerler etrafında bütünleştirir. Devlet, toplumsal düzeni sağlama adına zamanın kullanımından önceliklerimizin belirlenmesine kadar hayatın bütün alanlarında düzenleme yapabilecek (Bourdieu, 2015, s. 224) güce sahiptir. Bu anlamda devletler, ritüel oluşturmada dinden geri kalmamaktadırlar. Lefort bu durumu, "siyasal bir biçimin hazırlanmasıyla ilgili olan şey dinsel bir biçimin hazırlanmasıyla ilgili olan şeyden ayrılamaz" (akt. Abélés, 1998, s. 152) şeklinde ifade etmektedir. Bu bağlamda 15 Temmuz yeni bazı toplumsal kabullerin ve bunlar etrafında bazı ritüellerin hayatımıza girmesini beraberinde getirmiştir. Mesela; 'Demokrasi nöbeti' bunlardan biridir.

Sosyolojik anlamda iktidar, varlığını sürdürebilmek için insanları kendi gelecekleri üzerine düşünmeye ve muhasebe yapmaya zorlar. Bunu tertip ettiği belirli ritüeller üzerinden kitlelere aktarır. Kitlelerin bunu onaylaması için son derece zengin ve görkemli organizasyonlar tertip ederler (Abélés, 1998, s. 151). Lefort'un yukarıdaki tespitinden hareketle şunu söyleyebiliriz: Devlet, kendi geleceğini garanti altına almak için kendisi bazı ritüeller icat edebileceği gibi daha önce icat edilen dini, siyasi, kültürel, vb. ritüellerden ve bunların icra ediliş biçimlerinden de faydalanabilir. Bu anlamda 15 Temmuz ruhunu toplumun sahiplenmesi için dini alandan bazı sembollerin seçildiği dikkat çekmektedir. Dinin sosyal dayanışma ve birlik oluşturma gücünden yararlanılarak toplum, darbe 
karşıtlığı üzerinden din paydasında bir araya getirilmeye çalışılmıştır. Bayram, şehitlik ve gazilik gibi dini değerler demokrasinin tahkiminde kullanılmıştır.

\subsection{Temmuz Demokrasi ve Milli Birlik Günü ${ }^{3}$}

Her toplumda insanların hayatların derinden etkileyen bazı önemli olaylar vardır. Dügün, nişan, cenaze, kutlama, anma vb. etkinlikler günlük hayatın olmazsa olmazları arasındadır. Bunlara yakından bakıldığında her birinin simgesel içerik bakımından son derece zengin olduğunu görürüz. Mesela; dügünlerde özel giysilerin giyilmesi, evlenme dairesine özel şekilde bezenmiş bir otomobille gidilmesi, evlendirme memurunun özel bir konuşma yapması ve ardından imzaların atılması, gerek tek tek ve gerekse de toplu olarak ele alındığında toplumsal simge ve merasimlerin sosyal hayatta ne kadar önemli bir yer tuttuğunu göstermektedir (Mardin, 2013, s. 105-106). Bunlar etrafında hem toplumsal birliktelik yeniden örülmekte hem de kültür aktarımı gerçekleşerek mevcut sosyal sistemin yeniden üretimi sağlanmaktadır.

Gelenek, tarih yazımı, manzaralar, kurumlar, anıtlar, söylemler, vb. devlet hafızasının uzantıları doğrultusunda şekillendiğinden devletin hafızası bir anlamda bütün toplumu kuşatır (Nora, 2006, s. 160). Devletler tertip ettikleri ritüeller vasitasıyla yeni bir kolektif hafıza inşa ederler. Mesela; Cumhuriyet döneminde ilan edilen ulusal/milli bayramlar (23 Nisan, 29 Ekim, 19 Mayıs, 30 Ağustos) ve anma törenleri (10 Kasım gibi) bunlar arasında sayılabilir. Devlet bunu yaparken toplumsal ve tarihsel hafızadaki benzer uygulama ve örneklerden yararlanmıştır. Mesela; 19 Mayıs Gençlik ve Spor Bayramı İttihat ve Terakki iktidarı döneminde ilan edilen İdman Bayramı'nın bir devamıdır.

İdman Bayramı ilk defa I. Dünya Savaşı'nın hararetli günlerinde gençliği örgütleyip seferber etmek amacıyla 29 Nisan 1916 yılında İstanbul'da İttihad Spor Kulübü sahasında kutlanmıştır. Daha sonraki yıllarda bayramın ismi, kutlanma ayı ve günü pek çok kez değişikliğe uğramıştır. İdman Bayramı 1938 yılına kadar 'İdman Şenlikleri', 'Mektepler Bayramı', 'Mektepliler Bayramı', 'Jimnastik Şenlikleri', 'Jimnastik Bayramı' ve 'Okullar Bayramı' gibi isimler altında kutlanmıştır. 20 Haziran 1938'de TBMM almış olduğu bir kararla 19 Mayıs gününü "Gençlik ve Spor Bayramı" olarak kabul etmiş ve bayram uzun yıllar bu isimle kutlanmıştır. 12 Eylül'de darbeciler bayramın ismini 'Atatürk'ü Anma, Gençlik ve Spor Bayramı' (Alkan, 2011, s. 30-31) şeklinde tekrar değiştirmişlerdir. Bugün halen ayn isimle kutlanmaktadır.

Ritüel oluşturma çabalarının Cumhuriyetin kuruluşunu takip eden yıllardan sonra da devam ettiği görülmektedir. Mesela; 27 Mayıs 1960 darbesinden sonra darbeciler 27 Mayıs'1 "27 Mayıs Hürriyet ve Anayasa Bayramı" olarak ilan etmişlerdir. İki bayramın birbirine çok yakın olmasından ötürü bu tarihten itibaren 19 Mayıs 27 Mayıs'ın gölgesinde kalmaya başlamıştır (Alkan, 2011, 38). Türkiye'de 1963-1982 yılları arasında 19 yıl boyunca askerlerin demokrasiye müdahale etmesi bayram olarak kutlanmıştır. 28 Şubat (1997) sürecini takip eden yıllarda ulusalcı olarak tanımlanan çevreler tarafından Türkiye Cumhuriyeti'nin 75'nci kuruluş yıldönümünün bayram havasına dönüştürülerek, şölenselleştirilmeye çalışılması da bu kapsamda değerlendirilebilir.

Devlet, 15 Temmuz'u toplumsal hafızada kalıcı kılmak için 15 Temmuz kalkışması etrafında yeni bir toplumsal hafıza oluşturmaya çalışmaktadır. Mesela; askeri bir anlam çağrıştıran "nöbet" kavramının demokrasiye transfer edilerek, demokrasinin tıpkı vatan gibi

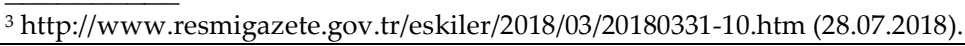

SEFAD, 2020; (43): 405-420 
nöbet tutarak korunması gereken bir 'üst anlatı' konumuna yükseltildiği dikkati çekmektedir. Halkın, yaklaşık bir ay süren "demokrasi nöbeti"ne gönüllü olarak katılımı sağlanarak sembolik açıdan asker rolünü oynamaya davet edildiği görülmektedir. Nasıl ki askerler nöbet tutarak muhtemel bir düşman istilasına karşı vatanı koruyorlarsa halk da demokrasi nöbetlerine katılarak olası bir darbe teşebbüsüne karşı demokrasiyi korumaya hazır halde tutulmuştur. 26 gün süren nöbet süresince halkın demokrasiye sahip çıması sağlanarak demokrasiye olan inanç tahkim edilmiştir. Demokrasi nöbeti $26^{\prime}$ ncı günün sonunda iktidar ve muhalefet partilerinin genel başkanlarının da katıldığı (HDP hariç) Yenikapı mitingiyle sona erdirilmiştir. Bu anlamda Yenikapı mitingi 15 Temmuz kalkışmasının toplum vicdanında daha önceki darbe ve darbe kalkışmalarından çok daha şiddetli bir şekilde kınandığını göstermektedir.

Bununla birlikte Devletin, kalkışmaya karşı koyma esnasında hayatını kaybedenlere "15 Temmuz Şehidi", yaralananlara da "15 Temmuz Gazisi" unvanlarını vermesi şehitlik ve gazilik literatürüne yeni bir eklemede bulunduğunu göstermektedir. Kurtuluş Savaşı şehitleri/gazileri, Kore Savaşı şehitleri/gazileri, Kıbrıs Savaşı şehitleri/gazilerine 15 Temmuz şehitleri/gazileri de eklenmiştir.

Geçmiş yıllarda demokratikleşme paketleri kapsamında ulusal bayramların kutlanmasına bazı kısitlamalar getirilse de 15 Temmuz sonrasında mevcut bayramlar silsilesine "15 Temmuz Demokrasi ve Milli Birlik Günü" ismiyle yeni bir bayramın eklenmesi Devlet'in geçmiş tecrübelerden yararlandığını göstermektedir. Devletin geçmiş toplumsal pratikleri ve toplumsal hafızayı takip ve taklit ederek biraz da refleksif bir tanımlamayla 15 Temmuz'u gelenekselleştirme noktasında geçmiş tecrübelerden yararlanma yoluna gittiği görülmektedir. Bu anlamda '15 Temmuz Demokrasi Bayramı' Cumhuriyet döneminde ilan edilen milli bayramlar zincirine eklenen son halkadır. Hatta son yıllarda Malazgirt Meydan Muharebesi'nin (1071) yıldönümü etkinliklerinin devlet törenine dönüştürülmesi siyasi hayatımıza yeni bir kutlama ritüelinin daha eklendiğini göstermektedir. 26 Nisan 1916'da Irak'ın Kut şehrinde yaklaşık 300 yıl sonra İngilizlere ağır bir mağlubiyet yaşatan Osmanlı Ordusu'nun bu galibiyeti son yıllarda Kut'ül Amare Zaferi ${ }^{4}$ olarak her yıl Nisan ayının sonlarında hükümet yetkililerince yeniden ülke gündemine taşınmasını buna örnek olarak verebiliriz. Kısaca ifade etmek gerekirse Türk demokrasi ve darbeler tarihine bakıldığında siyasal ritüel oluşturma girişimlerinin pek çok örneğine rastlamak mümkündür.

\subsection{Toplumsal Kimliğe “Anıt" Harcı}

Bir şeyin hatırlanabilmesi için toplumsal hafızada iz bırakması gerekmektedir. Toplum, sadece toplumsal hafızada iz bırakan anlamlı geçmişleri hatırlar. Hatırlanan geçmiş böylece aynı zamanda anlam da kazanmış olur. Her hatırlatma aynı zamanda bir göstergeleştirme eylemi (Assmann, 2015, s. 85) olduğundan hatırlamayı sürekli kılmak için son derece zenginleştirilmiş semboller eşliğinde bazı ritüeller icra edilmektedir. Törenlerin yinelenmesi/yenilenmesi üzerinden topluma geçmişin kesintisiz sürdüğü mesajı verilir (Connerton, 2014, s. 78). Mesela; toplumlar ölülerini anarak kimliklerini onaylamaktadırlar. Belirli isimlere bağlılık aynı zamanda sosyo-politik kimliğin onayını da içerdiğinden anma törenleri üzerinden bireysel ve kolektif bilinç tazelenerek kimlik yeniden inşa edilmektedir. Devlet'in 15 Temmuz şehitlerinin adını yaşatmak için Cumhurbaşkanlığı Külliyesi'nin

${ }^{4}$ https://www.bik.gov.tr/kutul-amare-zaferinin-onemi-nedir-savasi-kim-nasil-kazandi/ (Erişim Tarihi: 05 Aralık 2019). 
bahçesine "15 Temmuz Şehitleri Anıtı" yapılması ve şehitlerin her birisinin isminin anıta ayrı ayrı yazılması 15 Temmuz kalkışmasının Çanakkale Savaşı kadar önemli olduğunu göstermektedir. Benzer şekilde İstanbul'da darbeye karşı sivil direnişin simge mekânlarından biri olan Boğaziçi köprüsünün (15 Temmuz Şehitler Köprüsü) Anadolu yakası çıkışına da şehitler anıtı yapılmıştır. Ayrıca Bursa, Konya, Erzurum, Ordu, Denizli, Sivas, Niğde, Antalya, Hatay, Rize, Bilecik, Isparta ve daha pek çok vilayet ve ilçede 15 Temmuz temalı anıtlar inşa edilmiştir (Kavak, 2017).

Toplumlar sadece içsel iletişim biçimlerinin sahnesi olarak değil, aynı zamanda kimliklerinin sembolü ve hatıralarının dayanak noktası olarak bellek mekânları yaratarak toplumsal hafızayı garanti altına almaya çalışırlar. Grup ve mekân bir araya gelerek ortak bir sembolik yaşam kurarlar. Zaman zaman gruplar kendi mekânından ayrı düşseler de kutsal mekânları sembolik olarak yeniden üreterek bu birlikteliği yaşatırlar (Assmann, 2015, s. 47). Yılın belli dönemlerinde anıtlar ve abideler etrafında düzenlenen anma törenleri ve son derece zenginleştirilmiş semboller eşliğinde icra edilen ritüeller etrafında hissî ve duygusal birlik sağlanır.

İktidar ile hatırlama arasında ileriye dönük (prospektif) bir ittifak vardır. İktidarlar sadece geçmişte değil aynı zamanda gelecekte de hatırlanmak için kendilerini unutturmayacak işler yaparlar. Bunlar; eylemlerinin anlatılması, müziksel/müzikal olarak işlenmesi, anıtlarda sonsuzlaşması, arşivlenme vb. çabaları içerir. Bunlar üzerinden iktidarlar "kendisine geriye yönelik meşruluk ve ileriye yönelik ebedilik kazandırır"lar (Assmann, 2015, s. 79). Bu anlamda törenler iktidarın yeniden üretim işlevinin gerçekleşmesine önemli katkıda bulunurlar. Törenler bireylerin deneyimlerini yapılaştırmakta, algılamalarını şekillendirmekte ve gelecekten beklentilerini belirlemektedirler. Törenler üzerinden toplumda varolduğu düşünülen uzlaşma onaylanmakta, çatışmalar gizlenmektedir. Böylece hem toplumsal hiyerarşiyi hem de törenlerin içinde geliştiği cemaati pekiştirerek yöneticilerle yönetilenlerin bütünleşmesi sağlanmaktadır (Tekeli, 2009, s. 41-42).

Hatırlama kültürünün kökeni ölülerin anılmasına dayanmaktadır. Anma törenleri vasıtasıyla dün ile bugün arasında bir ilişki kurulur. Ölüm bu ayrımın mihenk noktasını oluşturur. Bu açıdan ölülerin anılması kültürel hatırlamanın ilk biçimini oluşturmaktadır (Assmann, 2015, s. 69). Anma törenleri esnasinda icra edilen ritüeller ve seremoniler sayesinde kolektif bilinç tazelenir. Mesela; Osmanlı döneminde padişahın tahta çıkarken cülus töreninin bir parçası olarak ecdadın türbelerine ziyarette bulunması, yeni padişahın bir öncekinin türbesini yaptırarak "Osmanlı hanedanının meşruiyeti ve sürekliliğini" vurgulayan bir anıt bırakması (Deringil, 2009, s. 65) bu anlamda değerlendirilebilir. Cumhuriyetin kurucusu Mustafa Kemal Atatürk'ün naaşının "Anıt Kabir" şeklinde topluma sunulması, 10 Kasım'da devlet erkânının Anıtkabir'i ziyaret etmesi ve Cumhurbaşkanı'nın Anıtkabir Özel Defteri'ne günün anlam ve önemini belirten bir mesaj yazması, TBMM'nin açılış dönemlerinde Meclis Başkanı'nın Anıtkabir'i ziyaret etmesi bu geleneğin kısmen de olsa (sadece devletin kurucusunun mezarının ziyaret edilmesi anlamında) devam ettiğini göstermektedir. Bunlar kurucu iradeye bağlılığın sembolik bir göstergesi olarak yorumlanabileceği gibi aynı zamanda kolektif hafızanın tazelenmesi olarak da yorumlanabilir.

15 Temmuz kalkışmasının seyrinin değişmesinde kilit rol oynayan şehit astsubay Ömer Halis Demir'in kahramanlı̆̆ının sembolleştirilmesi etrafında yeni bir hafıza oluşturulmaya çalışılmaktadır. 15 Temmuz sonrasında yayınlanan hemen hemen bütün 
görsellerde ona yer verilmiş, mezarına ziyaretler yapılmış, memleketindeki üniversite (Niğde Ömer Halis Demir Üniversitesi) başta olmak üzere çok sayıda kamu binasına onun adı verilmiştir. Ömer Halis Demir kadar simgeleşmese de darbe girişimi esnasında şehit olanların isimlerinin de benzer biçimde kamu binalarına verildiği görülmektedir. Milli Eğitim Bakanlığı 2016 yılında 40 ilde 47 okula 15 Temmuz'da şehit olan güvenlik güçleri ve sivil vatandaşların adını vermiştir (Milli Eğitim Bakanlığı, 2019).

\subsection{Demokrasi Yürüyüşü, Meydan ve Parklar}

Stadyumlar veya resmi gösteri amacıyla kurulmuş tören alanları ve meydanlar (Connerton, 2014, s. 109-110) kolektif bilincin inşasında kilit bir rol oynamaktadır. İlk kez Batı Avrupa'da ortaya çıkan bu simgeler sisteminin uluslaşma süreci içerisindeki tüm toplumlara (Özbudun, 1997, s. 127-128) yayıldı̆̆ görülmektedir. Osmanlının son dönemlerinde ve özellikle de Cumhuriyetin ilk yıllarında bunlarla ilgili pek çok örneğe rastlamak mümkündür.

Modernleşme sürecinde bazı ritüeller siyasi iktidarı topluma benimsetmek ve meşrulaştırma törenlerine dönüşmüştür. Siyasi iktidarın meşruiyeti kutsala dayandırılarak törenle/kutsalla ilişki içerisinde bu meşruiyet sağlanmaya çalışılmıştır (Tekeli, 2009, s. 41). Modern dönemde ulusal seçkinler bir yandan törenler, geçitler, mitingler örgütlerlerken diğer yandan da bunların nerede, ne zaman, nasıl icra edileceğiyle ilgili bir kurumsallaşmayı da beraberinde getirdiği görülmektedir. Diğer yandan da bu durum bu tür uygulamaların/pratiklerin nerede, ne zaman, nasıl icra edileceğiyle ilgili bir kurumsallaşmayı da beraberinde getirmektedir. Anma törenleri, bayramlar, kutlamalar, vb. ritüeller düşünüldüğünde bunların hazırlanması ve sunulması son derece uzun bir zaman almakta ve bu işlerle profesyonel ekipler ilgilenmektedirler. Ritüelleştirmenin gerçekleştirilmesinde protokol şefleri uzmanlaşmış profesyoneller olarak rehberlik etmektedirler (Abélés, 1998, s. 151).

Törenler esnasında icra edilecek ritüeller hukuki belgeler (kanun, yönetmelik, vb.) aracılığıyla en ince ayrıntısına kadar düzenlenmiştir. Mesela; Türkiye'de “Devlet görevlilerinin tören alanına giriş sırası, oturacakları yerler, tebrikleşme hiyerarşisi, törene katılacakların (kız öğrencilerin kurdelelerine varıncaya dek) kılık kıyafetleri, geçitlerdeki sıralama, (yapılacaksa) -1şıklandırmanın nasıl olacağı, Atatürk anıtlarına yerleştirilecek çelenklerin önem sırasına göre getirilişi, taşınma ve yerleştiriliş biçimi, bayrağın evsafı, göndere çekiliş şekli en ince ayrıntısına dek protokol ve yönetmeliklerde belirlenmiştir (Özbudun, 1997, s. 153-154)". Burada kendiliğindenliğe ve spontaneliğe yer yoktur. Belli bir disiplin ve hiyerarşi kendisini çok bariz bir şekilde hissettirmektedir.

\footnotetext{
"Resmî törenler, bir bakıma Cumhuriyet rejiminin 'ideal toplumu' arasındaki dengelerin sergilendiği bir sahnedir. 'Halk' bu törenlerde hiçbir şekilde katılımo olarak yer almaz, ancak izleyici olarak bulunmasına izin vardır. Törenlerin aslî unsurları, törenin kabulcüsü olarak her düzeydeki katılımları aralarındaki hiyerarşiye uygun olarak protokollerle belirlenen yöneticiler (askerî ve mülkî erkân) ve törensel geçide ve gösterilere katılan (bir bakıma töreni sunan) unsurlardır (29 Ekim ve 30 A ğustos'ta Askerî okul velveya birlikler, 19 Mayıs'ta ortaöğrenim gençliği, 23 Nisan'da ilköğrenim öğrencileri). Törenler Atatürk'ün manevî huzurunda yapılan bağhllık bildirimiyle başlar (bu, Başkent'te Anttkabir, diğer yerleşimlerde Atatürk ant, heykel ve büstlerine çelenk konulması ve saygı duruşunda bulunulması biçiminde gerçekleştirilir). Ardından ulusal birlik iradesinin bir ifadesi olmak üzere İstiklal Marşı söylenir ve göndere bayrak çekilir.
} 
Ardından mülkî ve İdarî amirler, protokolde belirlenen stralamaya göre tebrikleri kabul eder (Özbudun, 1997, s. 154)".

Kutlama, şenlik, festival, bayram vb. etkinliklerin her ne kadar önceden belirlenmiş bir izlencesi olsa da bunların en önemli özelliklerinden biri; belli ölçüde de olsa spontan ve kitlelerin katılımına açık olmasıdır (Tekeli, 2009, s. 38). Bellek her ne kadar bireye ait olsa da içeriği toplum tarafından belirlenir. Basit anlamda bireysel anılarımız bile sosyal etkileşim sayesinde oluşur (Assmann, 2015, s. 44). Ritüeller; ifade ve hareketlere dair özellikleri birleştirerek (Eriksen, 2012, s. 348) eylemleri, eylemler de inançları doğurur. Ritüel-eylem ve inanç ilişkisi bağlamında düşünüldüğünde yaklaşık olarak beş milyon kişinin katıldı̆̆ Yenikapı Mitinginin düzenlenmesinde demokrasi etrafında yeni bir birlik ruhu oluşturmaya yönelik bir çabanın yattı̆̆ını söyleyebiliriz. İktidar ve muhalefet partilerinin genel başkanlarının (HDP hariç) bu mitinge katılmaları modern Türkiye tarihi ve Türk demokrasisi açısından son derece önemlidir. Bu kolektif ruh oluşturma çabası her kesimden vatandaşın gönüllü katılımı ile sağlanmaya ve demokrasi bu ruh temelinde güçlendirilmeye çalışılmıştır. 15 Temmuz'un yıldönümlerinde demokrasi yürüyüşlerinin yapılması, pek çok şehirde meydan ve park isimlerinin demokrasi ön eki ile yeniden adlandırılması, bazı meydan ve parklara darbe girişimine direnirken yaşamını yitiren şehitlerin adının verilmesi bu kolektif kamusal hafızanın oluşturulmasına birer örnek olarak gösterilebilir. Ayrıca Boğaziçi Köprüsünün adı 15 Temmuz Şehitleri Köprüsü, Ankara Kızılay Meydanı'nın adı 15 Temmuz Kızılay Milli İrade Meydanı, Diyarbakır Parkorman Parkı, 15 Temmuz Şehitler Parkı adını almıştır. Mardin, Van, Kayseri, İzmit, Konya, A ğrı, Tunceli ve pek çok il ve ilçede park ve meydanlara belediye meclisleri tarafından 15 Temmuz adı verilmiştir.

\section{SONUÇ}

Toplumun, geleceğini tehdit eden de facto durumlar karşısında kolektif bilinç kendiliğinden devreye girer. Nasıl ki Kurtuluş Savaşında halk yediden yetmişe işgalcilere karşı varını yoğunu ortaya koyarak direnmişse aynı ruh yüz yıl sonra tekrar ortaya çıkarak 15 Temmuz gecesi kendisini göstermiştir. Kalkışmanın ilk saatlerinden itibaren bunun halk tarafından uluslararası destekli bir işgal girişimi olarak algılanması kolektif bilinci harekete geçirerek haklın inisiyatif almasını kolaylaştırmıştır.

15 Temmuz ardından Devletin, toplumun tamamına hitap etme adına dinî, askeri ve kamusal alanlardan seçmiş olduğu belli simge ve semboller ve bunlar etrafında üretilmeye çalışılan bazı ritüellerle yeni bir birliktelik ruhu oluşturmaya çalıştığı dikkati çekmektedir. İlgili sahalardan özenle seçilen semboller üzerinden yeni bir siyasal bellek oluşturmak için kodlama yapılmaktadır. 15 Temmuz sonrasında geliştirilen bazı eylem ve söylemlerin resmileştirilmesi ile demokratik bilincin derinleştirilmesi ve demokrasinin kurumsallaştırılması çabasının güdüldüğü dikkati çekmektedir. $\mathrm{Bu}$ durum önceki dönemlerde daha fazla demokrasi olursa rejim elden gider endişesinin yerini daha fazla demokrasi olursa toplumsal yapı daha güçlü hale gelir'e bıraktığının bir göstergesi olarak okunabilir.

Demokratik bilinç ve yönetim bireysel ve kolektif şuurun gelişmesi ile ortaya çıkar, kendine uygulama zemini bulur, seçim, siyasal parti, eşit ve gizli oy, açı sayım, özgür propaganda gibi araçları, siyasi iradeye bağlı olarak faaliyet gösteren bürokratik birimleri ile kurumsallaşır. 15 Temmuz ardından farklı alanlardan tevarüs ettirilen sembol, simge, ritüeller bu demokratik bilincin gelişmesini sağlamak amacıyla kullanılmıştır. 15 Temmuz

SEFAD, 2020; (43): 405-420 
sonrası yapılan yasal düzenlemeler ve sosyal kutlamalar bir yandan demokrasiyi tahkime yönelirken diğer yandan demokrasinin kurumsallaşacağı bir toplumsal zeminin oluşmasına hizmet etmektedir. 15 Temmuz'la ilgili hızla ciddi bir literatür oluşmaktadır. Önümüzdeki yıllarda bu verilerin iyi analiz edilmesi durumunda çok daha nitelikli çalışmalar yapilabilecektir.

\section{SUMMARY}

Despite approximately 150 years of history of democracy in Turkey, military-civilian and military-politician relations have always been problematic. This process has also brought a culture by which some groups in military interfere in politics at certain intervals and transfer the administration back to civilians after a while. There are very effective elements in the formation of this culture when the mentioned groups interfere in politics because the public stays silent against these interferences, politicians do not resist against coup plotters and some of the effective countries support these coups. Pro-coup soldiers in the army intervened in politics directly or indirectly in the Republican era many times because they perceived the public not to resist as an implicit support.

The last case of it is the military attempt on 15 July 2016 organized by the Fethullahist Terrorist Organization (FETO) members who were organized secretly within Turkish Armed Forces (TSK). The most important feature of July 15 coup attempt differing from the other memorandum and military attempts is that it is an attempt motivated by the religion and, contrary to the expectations of the coup plotters, the public plays a vital role in repulsing the coup by demonstrating a civil resistance against the soldiers. Furthermore, the resistance of those who did not participate in the coup within the army, the resistance of the government forces such as police and special operations, the judiciary's arrest and detention orders against coup plotters, and of course some activities of other institutions were also effective in disrupting the coup.

After disrupting July 15 coup attempt, council of ministers convened under the presidency of the President announced state of emergency (OHAL) for 3 months starting from 21 July 2016. In the following periods, OHAL was extended periodically for 7 times, each for 3 months and Turkey was administrated under OHAL until 18 July 2018. During OHAL process, FETO members who worked under public service were laid off from their jobs or discarded with delegated legislations (KHK) and public institutions are reorganized while other values such as martyr/veteran and valour values which were selected in religion, military and democratic areas to redintegrate the society. By this way, a new culture was built for public awareness as well as July 15 has been made permanent in public memory. This process still continues.

Although only a few years have passed after July 15 coup attempt, it is observed that a serious academic literature is rapidly developing (with the encouragement of the state) regarding July 15 coup attempt. We can briefly classify the works by theme as follows: the difference of July 15 coup attempt from other previous military attempts and memorandum, the role of media in disrupting the coup, the resistance of the public against the coup, the determination of the public to defend freedom and democracy, the international powers behind the coup, the economic effects of July 15 coup attempt, the problems that Turkey face during explanation of July 15 coup attempt to international public opinion. The most important difference of this study from the previous works made in this is; it deals with a 
symbolic interactionist perspective on how the state is trying to strengthen both public order and democracy around some common values selected from the religious, military and civil / public sphere.

The symbolic interactionist approach commonly used in sociological researches in the study claims that the ways of thinking and reasoning of individuals are shaped by the society. The individuals continue their relationship with other individuals, public and state via the meanings and symbols which they have learned during socialization. Sociological interpretation of signs, symbols and rituals, which form the basis of social interaction and action patterns, has a key role in understanding society. Based on this assumption, the study examines the effect of systematically selected common values from religious, military and civil / public spheres on the integration of society around democracy. In this context;

Firstly, rituals as symbolic expressions of social order are discussed. Ritual is a social definition and is the means of social construction. States can build some rituals to secure their future, as well as take advantage of religious, political and cultural rituals previously performed. The state also tried to bring the society together in the anti-coup denominator over religion by taking the advantage of religion's social solidarity and unity function. Religious values such as holidays, martyrdom and veterans were used for the strengthening of democracy.

Secondly, historiography is shaped by the extensions of the state memory. States construct a new collective memory by ritualizing events such as holidays, celebrations and commemorations. And while doing these, they use similar practices and / or examples which are in the social memory. For example, May 19 Youth and Sports Day is a continuation of İdman Bayramı (1916) which was announced during the Committee of Union and Progress. In the years following the foundation of the Republic, April 23, October 29, May 19, August 30, and "Freedom and Constitution Day" was added by May 27 coup and abolished by 12 September 1980 coup. In order to make July 15 permanent in social memory, the state has declared "July 15 the Day of Democracy and National Unity". In addition, the concept of seizure, which evokes a military meaning, has been transferred to the democracy and raised to the position of a superior narrative that needs to be protected by keeping the seizure as homeland. The Yenikapı public meeting gives the impression that July 15 coup attempt has been rejected very strongly in the conscience of the society.

Thirdly, it is the transfer of the past to future generations through the monuments made on behalf of the martyrs and veterans of July 15. Through the monuments built for commemoration ceremonies and the ceremonies performed around them, cultural transfer takes place by renewing individual and collective consciousness. Thus, a connection is made between yesterday and today, and today and tomorrow. In this sense, in order to perpetuate the name of July 15 martyrs, "July 15 the Monument of Martyrs" was built in the garden of the Presidency Social Complex to remind how important July 15 coup attempt is in terms of modern Turkey's history.

To put it briefly, it is seen that after July 15 coup attempt, the state tried to create a new spirit of social unity/common values which were selected from religious, military and civil / public spheres in order to address the whole society. This situation can be read as an indication that if there was more democracy in the previous periods, the worry that the regime was lost is replaced by social structure becomes stronger if there is more democracy.

SEFAD, 2020; (43): 405-420 


\section{KAYNAKÇA}

Abélés, M. (1998). Devletin antropolojisi. (N. Ökten, Çev.). İstanbul: Kesit Yayıncllık.

Alkan, M. Ö. (2011). Osmanlı idman bayramı'ndan Atatürk'ü anma, Gençlik ve Spor Bayramına (en doğru bildiğimizden kuşkulanmak-6). Toplumsal Tarih. No: 211 (Temmuz 2011), 30-41.

Assmann, J. (2015). Kültürel bellek. (A. Tekin, Çev.). İstanbul: Ayrıntı Yayınları.

Barlas, M. (2000). Türkiye'de darbeler ve kavgalar dönemi. İstanbul: Birey Yayınları.

Bayramoğlu, A. (2018). 28 Şubat bir müdahalenin güncesi. İstanbul: İletişim Yayınları.

Bourdieu, P. (2015). Devlet üzerine. (A. Sümer, Çev.). İstanbul: İletişim Yayınları.

Connerton, P. (2014). Toplum nasıl anımsar?. (A. Şenel, Çev.). İstanbul: Ayrıntı Yayınları.

Çaha, Ö. (2011). Demokrasi. İçinde. (Ed. Halis Çetin). Siyaset Bilimi. (205-238). Ankara: Orion Kitabevi.

Deringil, S. (2009). Simgeden millete. İstanbul: İletişim Yayınları.

Eriksen, T. H. (2012). Sosyal ve kültürel antropoloji. (A. E. Koca, Çev.). Ankara: Birleşik Dağıtım.

Findley, C. V. (2011). Modern Türkiye tarihi. (G. Ayas, Çev). İstanbul: Timaş Yayınları.

http://www.resmigazete.gov.tr/efskiler/2018/03/20180331-10.htm (28.07.2018).

https://onedio.com/haber/15-temmuz-sonrasi-ilk-anket-sokaga-kimler-cikti-tehlike-gecti-mi-724413 (28 Ocak 2019).

https://www.bik.gov.tr/kutul-amare-zaferinin-onemi-nedir-savasi-kim-nasil-kazandi/ (Erişim Tarihi: 05 Aralık 2019).

Karaman, K. (2010). Ritüellerin toplumsal etkileri. SDÜ Fen Edebiyat Fakültesi Sosyal Bilimler Dergisi. 227-236.

Kavak, Y. E (2017). İşte Türkiye'nin 15 temmuz anıtları, Sabah, (23.07.2017). İşte Türkiye'nin 15 Temmuz anitları, https://www.sabah.com.tr (25.11.2019).

Koçak, C. (2017). Darbeler tarihi. İstanbul: Timaş Yayınları.

Mardin, Ş. (2013). İdeoloji. İstanbul: İletişim Yayınları.

Marshall, G. (1999). Sosyoloji sözlü̈̆̈̈. (O. Akınbay ve D. Kömürcü, Çev.). Ankara: Bilim ve Sanat Yayınları.

Milli Eğitim Bakanlığı (2019). 15 temmuz şehitlerinin adları okullarda yaşatılıyor. http://ogm.meb.gov.tr (22.11.2019).

Nora, P. (2006). Hafıza mekânları. (M. E. Özcan, Çev.). Ankara: Dost Kitabevi.

Ortaylı, İlber (2001). Gelenekten geleceğe. İstanbul: Ufuk Kitapları.

Özbudun, S. (1997). Ayinden törene. İstanbul: Anahtar Kitaplar.

Ritzer, G. (2011). Modern sosyoloji kuramları. (H. Hülür, Çev.). Ankara: De Ki Yayınları.

Schmitt, C. (2005). Siyasi ilahiyat. (E. Zeybekoğlu, Çev.). Ankara: Dost Kitabevi.

Tekeli, İ. (2009). Gündelik yaşan, yaşam kalitesi ve yerellik yazıları. İstanbul: Tarih Vakfı Yurt Yayınları.

Tunçay, M. (2015). Türkiye Cumhuriyeti'nde tek parti yönetimi'nin kurulmast 1923-1931. İstanbul: Tarih Vakfı Yurt Yayınları.

Yetkin, Ç. (2011). Türkiye'de askeri darbeler ve Amerika. İstanbul: Kilit Yayınları. 